\title{
Counterproductive work behaviors within academic institutions: A myth or a reality
}

Ching, Gregory S.

Graduate Institute of Educational Leadership and Development, Fu Jen Catholic University, Taiwan (gregory_ching@yahoo.com; 094478@mail.fju.edu.tw)

\section{Tsay, Wen-Rong}

Institute of Professional Development for Educators, National Chung Hsing University, Taiwan (wtsay@dragon.nchu.edu.tw)

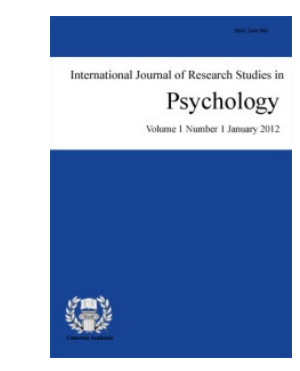

ISSN: 2243-7681 Online ISSN: 2243-769X

OPEN ACCESS

$\mathrm{Hu}$, Yueh-Luen

Department of Education, National Chengchi University, Taiwan (joyhu@nccu.edu.tw)

Hung, Chao-Hsiang

Department of Education, National Chengchi University, Taiwan (aka0518@gmail.com)

Received: 3 July $2016 \quad$ Revised: 28 September $2016 \quad$ Accepted: 5 October 2016

\section{Abstract}

Recent studies in counterproductive work behavior (CWB) have noted the seriousness of having deviant behaviors within the workplace environment. Acknowledging that CWBs exists in all types of organization; this would mean that even within academic institutions, occurrence of CWBs is inevitable. Within an initial study of CWBs in Taiwan academic institutions, results suggest a moderate occurrence of some serious negative behaviors. To clarify their findings, further validation of the CWB-T is needed. In the spring semester of 2015, an online survey was established and data was collected from strategically selected schools all over Taiwan. After three weeks of data collection, a total of 718 valid responds are noted and analyzed. Using the CWB-T framework, eight (8) factors are validated using Structured Equation Modelling (SEM). In addition, various demographical backgrounds are also collected and analyzed. Results suggest that teachers with administrative responsibilities, teachers with longer years of service, teachers working in urban cities, and teachers who are working in the key capital region all seem to perceived higher occurrence of CWBs within the academic workplace. In essence, it is currently noted that even within school, CWBs are occurring from low to moderate. Therefore, it is imperative that awareness of such deviant behaviors be achieved and further escalation be prevented.

Keywords: work attitude; teacher; social desirability; deviant behavior; organizational behavior 


\section{Counterproductive work behaviors within academic institutions: A myth or a reality}

\section{Introduction}

Counterproductive work behavior (CWB) is an issue that exists in all areas within the workplace (Spector et al., 2006), this is also quite true within educational institutions (Hu, Hung, \& Ching, 2015). Many have also tried to further explain the relationship between CWB and organizational citizenship behavior (OCB), which are noted to show some significant connections (Dalal, 2005). Noting the positive role of OCB within educational institutions (Belogolovsky \& Somech, 2010; Oplatka, 2009), however, with the pressure involved within the academic career (Fox \& Stallworth, 2010), CWB would seem to be a type of normal response for teachers under such circumstances (Fox, Spector, \& Miles, 2001). In essence, teachers are also normal individuals, hence exhibits similar behaviors as of the typical employees (Bayram, Gursakal, \& Bilgel, 2009). Nevertheless, CWB is still considered quite harmful to both the people working within and to the organization itself (Gruys \& Sackett, 2003; Robinson \& Bennett, 1995; Sackett, 2002). Therefore, in order to prevent the current situation from getting worst, it is quite important to truly understand and determine the various CWBs that are currently happening inside the school.

As mentioned, CWB can be harmful to both people and organization. CWBs also comes in different levels, some minor issues might include deliberately coming late to work, or to the very serious incidents, such as theft and deliberate waste of organizational resources. Within $\mathrm{Hu}$ and her colleagues (2015) recent study, they suggest that CWBs can be differentiated with either the common ones or to the very serious offenses. In their initial findings, they mentioned that there exists a certain amount of serious CWBs in Taiwan schools (Hu et al., 2015). While, in a study on secondary school teachers in Nigeria, Salami (2010) mentioned that work related stress and negative affectivity are two crucial predictors for CWB. As with the stressful nature of academic work in Taiwan (Hung, 2011; Kyriacou \& Chien, 2004), occurrence of deviant behaviors are inevitable. More important, CWB studies in Taiwan are quite limited, hence, the current study shall attempt to further verify the CWB Taiwan (CWB-T) scale (Hu et al., 2015) within the elementary and high school teachers.

Within the CWB-T scale a total of 8 factors are mentioned, namely: time theft (TT) - reducing work hours using any form of improper or inappropriate reasons, inappropriate use of resources (IUR) - deliberate use, waste, theft, or destruction of schools' properties, inappropriate student-teacher relationship (ISR) - any inappropriate, unethical, or unprofessional interactions between teachers and students, inappropriate parent-teacher relationship (IPR) - any inappropriate, unethical, or unprofessional interactions between teachers and parents, lack of professionalism (LOP) - lack of pedagogical and professional content knowledge resulting in poor teaching performance, apathy (AP) - lack of enthusiasm and/or unwilling to improve oneself, political tactics (PT) - forming alliances to gain control and personal attacks, and reluctant to accept administrative duties (RAD) - unwilling to accept any duties besides teaching (Hu et al., 2015, p. 71). CWB-T scale is computed to have Cronbach (1951) alpha reliabilities ranging from .73 to .90 , denoting quite a reliable instrument (Cohen, Manion, \& Morrison, 2007). Therefore, it would seem appropriate to validate the CWB-T and at the same time administering it to wider participants.

\section{The study}

In order to determine the state of CWB within Taiwan schools, participants of the study are volunteer elementary and high school teachers from strategically selected schools all over Taiwan from the 2014-15 Ministry of Education database. After selecting the schools, invitation for volunteer participation were emailed. After 3 weeks, a total of 718 respondents were collected. Table 1 shows the various demographical backgrounds of the respondents, note the deliberate diverse characteristics of the respondents are selected to provide better coverage (Weisberg, Kronsnick, \& Bowen, 1996). Furthermore, for ethical purposes, during the survey 
administration participants are free to skip any questions that they would prefer not to answer (Walker, 2010).

Table 1 shows the various demographics with the corresponding number of participants. Results show that the proportion of male and female respondents is almost equal with 372 or $52 \%$ male teachers and 343 or $48 \%$ female teachers. While, there are 216 or $30.1 \%$ subject teachers, 245 or $34.1 \%$ teachers with class adviser duties, 185 or $25.8 \%$ teachers with administrative responsibilities/positions, 40 or $5.6 \%$ administrative staff, and 26 or $3.6 \%$ school principals. As for their educational attainment, 328 or $45.7 \%$ are college/university graduate (bachelor degree), 379 or $52.8 \%$ are master degree holders, and 8 or $1.1 \%$ are doctoral degree holders. For the years of service, almost half of the participants or 348 teachers worked for less than 10 years, while the rest are less than 20 years, while 69 or $9.6 \%$ of the teachers have worked for 21 to 25 years, and 10 or $1.4 \%$ of the teachers have more than 26 years of experience in teaching.

For the geographical location, majority of the participants are actually from two areas namely: Northern Taiwan with 310 or $43.2 \%$, Central Taiwan with 343 or $47.8 \%$, while the remaining participants are from the Southern with 60 or $8 \%$ and Eastern Taiwan with 5 or $1 \%$. For the school size, majority of the participants worked in schools with 13 to 48 classes; categorized as middle school by the MOE (313 or $43.6 \%$ ) and schools with more than 49 classes; big schools (330 or 46\%). Lastly, for the school districts, participants who worked in urban/city schools with 490 or $68.2 \%$, rural schools with 186 or $25.9 \%$, and remote schools with 42 or $5.8 \%$.

Table 1

Participants' demographic background $(N=718)$

\begin{tabular}{|c|c|c|}
\hline Items & $n$ & $\%$ \\
\hline \multicolumn{3}{|l|}{ Gender } \\
\hline Male & 372 & 52 \\
\hline Female & 343 & 48 \\
\hline \multicolumn{3}{|l|}{ Role } \\
\hline Subject teacher & 216 & 30 \\
\hline Teacher (+ class adviser) & 245 & 34 \\
\hline Teacher (+ administrator) & 185 & 26 \\
\hline Administrative staff & 40 & 6 \\
\hline School Principal & 26 & 4 \\
\hline \multicolumn{3}{|l|}{ Education level } \\
\hline College & 328 & 46 \\
\hline Master & 379 & 53 \\
\hline Doctor & 8 & 1 \\
\hline \multicolumn{3}{|l|}{ Years of service } \\
\hline 1 to 5 years & 179 & 25 \\
\hline 6 to 10 years & 169 & 24 \\
\hline 11 to 15 years & 118 & 16 \\
\hline 16 to 20 years & 126 & 18 \\
\hline 21 to 25 years & 69 & 10 \\
\hline More than 26 years & 10 & 1 \\
\hline \multicolumn{3}{|l|}{ Geographical location } \\
\hline North Taiwan & 310 & 43 \\
\hline Central Taiwan & 343 & 48 \\
\hline South Taiwan & 60 & 8 \\
\hline East Taiwan & 5 & 1 \\
\hline \multicolumn{3}{|l|}{ School size } \\
\hline Less than 12 classes & 74 & 10 \\
\hline Between 13 to 48 classes & 313 & 44 \\
\hline More than 49 classes & 330 & 46 \\
\hline \multicolumn{3}{|l|}{ District } \\
\hline Urban/City & 490 & 68 \\
\hline Rural & 186 & 26 \\
\hline Remote & 42 & 6 \\
\hline
\end{tabular}




\subsection{Issues of social desirability}

In order to prevent the issue of social desirability in affecting the self-reported survey, some statistical considerations were implemented. Following the design in the initial study of Hu et al. (2015) for the CWB-T, the perceived frequency of the various deviant practices, which is initially outline with Likert (1932) type scale ranging from 0 to 3 ; denoting never to always. In order to account for the effects of social desirability, the survey is recoded into either $\boldsymbol{O}$ for none occurrence and $\boldsymbol{l}$ for possible occurrence. Afterwards, reliability of the CWB-T factors is recomputed. Table 2 shows that the Cronbach (1951) alpha reliabilities before (original) and after (transformed) the recoding. Note that majority of the reliabilities improved slightly, hence, the transformed reliabilities ranges from .72 to .90 , denoting a reliable instrument (Cohen et al., 2007).

\section{Table 2}

Reliability of CWB-T factors

\begin{tabular}{|c|c|c|}
\hline \multirow{2}{*}{ Factors } & \multicolumn{2}{|c|}{ Cronbach Alpha } \\
\hline & Original & Transformed \\
\hline TT & .81 & .81 \\
\hline IUR & .71 & .72 \\
\hline ISR & .84 & .86 \\
\hline IPR & .82 & .82 \\
\hline LOP & .81 & .84 \\
\hline AP & .83 & .82 \\
\hline PT & .92 & .90 \\
\hline RAD & .78 & .79 \\
\hline
\end{tabular}

Besides the recoding of perceived CWB occurrence, a social desirability scale was also administered together with the survey. The current study employed the Fischer and Fick (1993) short version of the Marlowe-Crowne Social Desirability Scale (SDS), which is highly tested for its reliability in predicting socially conscious participants (Andrews \& Meyer, 2003; Barger, 2002; Leite \& Beretvas, 2005; Loo \& Thorpe, 2000; Thompson \& Phua, 2005). To check for social desirability issues, correlations were computed between the CWB-T factors and SDS. Table 3 shows that majority (6 out of 8 ) of the factors are not significantly correlated to SDS, hence, can be considered as reliable results. While, two of the CWB-T factors ISR and LOP might be slightly influenced by individual social desirability tendencies.

\section{Table 3}

Correlation of CWB-T factors with SDS

\begin{tabular}{ll}
\hline \multicolumn{1}{c}{ Factors } & SDS \\
\hline TT & .030 \\
IUR & .070 \\
ISR & $.087^{*}$ \\
IPR & .030 \\
LOP & $.076^{*}$ \\
AP & .060 \\
PT & .050 \\
RAD & -.020 \\
\hline Note. $*<.05$ (2-tailed) &
\end{tabular}

\subsection{Factor analysis of CWB-T}

To evaluate the CWB-T scale, confirmatory factor analysis (CFA) is accomplished using the structured equation modelling (SEM). Analysis followed the concepts mentioned in Kenny's (2016), resulting with a good model fit (Kenny, 2015) with $\chi^{2}=2870.97^{* * *}, d f=961$, GFI $=.93$, CFI $=.91$, TLI $=.92$, NFI $=.93$, RMSEA $=.053, \mathrm{SRMR}=.046$. Furthermore, Table 4 shows the various factor loadings with values above .5 and Average Variance Extracted (AVE) ranging from $46 \%$ to $63 \%$, while the Composite Reliability (CR) are well above .7, 
denoting reliable CFA (Fornell \& Larcker, 1981). In addition, Table 5 also shows the various inter-correlations of the CWB-T factors, denoting significant relationships among all of the indicators of CWB in Taiwan educational setting. In other words, the CWB-T can be considered as a reliable instrument.

Table 4

Confirmatory factor analysis of $C W B-T$

Factors/Items

TT

$\begin{array}{ccc}\begin{array}{c}\text { Standardized } \\ \text { factor loading }\end{array} & S E & t \\ .65 & & \\ .66 & 0.08 & 15.09 \\ .66 & 0.07 & 15.18 \\ .69 & 0.07 & 15.61 \\ .70 & 0.07 & 15.79 \\ .74 & 0.08 & 16.49 \\ .73 & 0.08 & 16.38\end{array}$

Lying about being sick

Leaving without asking for leave

Coming to school late and/or going home early

Asking for leave regardless of the work situation

Doing personal stuff while on duty

Being online (personal internet surfing; FB) while on duty

Chatting while on duty

$$
\text { IUR }
$$

Waste of school's resources

Occupying school's resources as if one's own property

Stealing school resources

Destruction of school's resources

\section{ISR}

Favoritism or discriminating specific students

Improper student punishment

Mocking students

Discrimination against students

Deliberate singling out of specific students

Focusing only on students with good grades and ignoring others

Separated and cold towards students' problems

IPR

$0.07 \quad 14.90$

$0.08 \quad 15.83$

$0.06 \quad 14.66$

$0.07 \quad 15.54$

$0.08 \quad 15.51$

$0.08 \quad 15.78$

Deliberate concealment or providing misleading information

Improper behavior in front of parents

Encouraging parents to go against the school

Conniving with parents

Ignoring or unwilling to communicate with parents

$$
\text { LOP }
$$

$0.04 \quad 20.66$

$0.04 \quad 17.62$

$0.03 \quad 14.50$

$0.04 \quad 19.69$

Inadequate teacher preparation

Not following proper curriculum

Saying improper things during class

Too few or too much assignments/class activities

Casual checking of students' assignments

Improper use of teaching pedagogy (such as too much movie time)

$$
\text { AP }
$$

Unwilling to undergo tutoring

Lacks teaching enthusiasm

Wrong use of educational resources

Lacks professional content knowledge

Unwilling to participate in professional development workshops

Lacks the motivation to join professional development programs

$$
\text { PT }
$$

\section{PT}

$0.06 \quad 16.71$

$\begin{array}{ll}0.06 & 17.91\end{array}$

$0.06 \quad 15.67$

$0.05 \quad 17.72$

$0.06 \quad 16.27$

$0.06 \quad 16.10$

$0.06 \quad 15.03$

$0.05 \quad 13.65$

$0.07 \quad 18.75$

$0.07 \quad 18.65$

$.61 \quad .92$

Gossiping

Spreading wrong/bad information

$\begin{array}{ll}0.05 & 20.39\end{array}$

Improver verbal conduct

$0.05 \quad 19.67$

Deliberate neglect or ignoring others

$0.05 \quad 20.75$

Deliberate singling out others

$0.05 \quad 21.94$

Forming small groups/alliances to go against others

$0.05 \quad 21.17$

Convincing others to go against the school

$0.05 \quad 20.83$ 
Ching, G. S., Tsay, W.-R., Hu, Y.-L., \& Hung, C.-H.

Table 4 continued ...

\begin{tabular}{|c|c|c|c|c|c|}
\hline Factors/Items & $\begin{array}{l}\text { Standardized } \\
\text { factor loading }\end{array}$ & $S E$ & $t$ & AVE & CR \\
\hline RAD & & & & .50 & .79 \\
\hline Unwilling to cooperate with school administration & .85 & & & & \\
\hline Going against all educational reforms & .73 & 0.04 & 20.98 & & \\
\hline Unwilling to undertake administrative responsibilities & .69 & 0.06 & 19.60 & & \\
\hline Miscommunication between teachers and administrators & .50 & 0.06 & 12.80 & & \\
\hline
\end{tabular}

Note. All standardized factor loading are significant with $p<.001$.

\section{Table 5}

Correlation analysis between CWB-T factors

\begin{tabular}{|c|c|c|c|c|c|c|c|c|c|c|c|}
\hline Factors & Mean & $S D$ & Skew & (1) & (2) & (3) & (4) & (5) & (6) & (7) & (8) \\
\hline (1) TT & 0.65 & 0.30 & -.64 & 1 & & & & & & & \\
\hline (2) IUR & 0.29 & 0.30 & .67 & .84 & 1 & & & & & & \\
\hline (3) ISR & 0.49 & 0.35 & .03 & .83 & .82 & 1 & & & & & \\
\hline (4) IPR & 0.28 & 0.34 & .90 & .70 & .73 & .85 & 1 & & & & \\
\hline (5) LOP & 0.54 & 0.37 & -.14 & .70 & .74 & .71 & .73 & 1 & & & \\
\hline (6) AP & 0.59 & 0.34 & -.35 & .77 & .77 & .74 & .69 & .61 & 1 & & \\
\hline (7) $\mathrm{PT}$ & 0.46 & 0.38 & .21 & .63 & .72 & .74 & .81 & .80 & .60 & 1 & \\
\hline (8) RAD & 0.61 & 0.37 & -.40 & .71 & .67 & .69 & .67 & .60 & .84 & .60 & 1 \\
\hline
\end{tabular}

Note. All correlations are significant with $p<.001$ (2-tailed).

\section{Results and discussions}

With a reliable instrument, appropriate analysis can now be accomplished. Table 6 shows the mean scores of the CWB-T factors. Results indicate that several factors such as: LOP (M=0.54), AP (M=0.59), RAD (M=0.61), and TT $(M=0.65)$ seems to be perceived as occurring in the workplace, while ISR $(M=.49)$ and PT $(M=0.46)$; with mean scores almost 0.50 , also seems to be present within schools. The remaining CWB-T factors IPR $(M=0.28)$ and IUR $(M=0.29)$ indicates that these deviant behaviors seems unlikely or less chances of occurring. Furthermore, to better understand CWB, gender analysis was also accomplished. Table 7 shows that only ISR with $t(713)=1.960, p=.050$ and $\mathrm{RAD}$ with $t(713)=2.991, p=.003$, denoting female teachers perceived higher occurrence of CWBs than male faculty counterparts.

Table 6

$C W B-T$ mean scores $(N=718)$

\begin{tabular}{lcc}
\hline \multicolumn{1}{c}{ Factors } & Mean & $S D$ \\
\hline TT & 0.65 & 0.30 \\
IUR & 0.29 & 0.30 \\
ISR & 0.49 & 0.35 \\
IPR & 0.28 & 0.34 \\
LOP & 0.54 & 0.37 \\
AP & 0.59 & 0.34 \\
PT & 0.46 & 0.38 \\
RAD & 0.61 & 0.37 \\
\hline
\end{tabular}

For the perceived differences between teachers roles, Table 8 shows the Analysis of Variance (ANOVA) results noting significant differences in all of the CWB-T factors with $F$ values ranging from 11.054 to 19.707 all with $p=.001$. As for the post-hoc analysis, significant differences were computed with Teachers with administrative duties and School principals perceiving significant higher CWB occurrences (in all of the eight factors) as compared to the other faculty. In addition, with some instances such as within the factors PT and RAD, School administrative staff perceived significant higher CWB occurrences as compared to Subject teachers and Teachers with class advising duties. Such findings clearly show that having administrative duties seems to provide better opportunities for the participants to observe what is really happening inside the school. 
Counterproductive work behaviors within academic institutions: A myth or a reality

Furthermore, as with the participants' roles are related to their time spent in schools, such as teacher with administrative duties sometimes stayed late in the office, hence, better chance of encountering and identifying deviant behaviors that occurs within the school.

Table 7

Gender differences among CWB-T factors $(N=718)$

\begin{tabular}{|c|c|c|c|c|c|c|}
\hline Factors & Gender & $n$ & Mean & $S D$ & $t$ & $\eta^{2}$ \\
\hline \multirow[t]{2}{*}{$\overline{\mathrm{TT}}$} & Female & 343 & 0.67 & 0.31 & 1.348 & .003 \\
\hline & Male & 372 & 0.64 & 0.30 & & \\
\hline \multirow[t]{2}{*}{ IUR } & Female & 343 & 0.30 & 0.30 & 0.830 & .001 \\
\hline & Male & 372 & 0.28 & 0.30 & & \\
\hline \multirow[t]{2}{*}{ ISR } & Female & 343 & 0.52 & 0.35 & $1.960 *$ & .005 \\
\hline & Male & 372 & 0.47 & 0.34 & & \\
\hline \multirow[t]{2}{*}{ IPR } & Female & 343 & 0.30 & 0.34 & 1.045 & .002 \\
\hline & Male & 372 & 0.27 & 0.34 & & \\
\hline \multirow[t]{2}{*}{ LOP } & Female & 343 & 0.55 & 0.37 & 0.909 & .001 \\
\hline & Male & 372 & 0.53 & 0.36 & & \\
\hline \multirow[t]{2}{*}{$\overline{\mathrm{AP}}$} & Female & 343 & 0.61 & 0.35 & 1.267 & .002 \\
\hline & Male & 372 & 0.58 & 0.34 & & \\
\hline \multirow[t]{2}{*}{$\overline{\mathrm{PT}}$} & Female & 343 & 0.48 & 0.37 & 1.556 & .003 \\
\hline & Male & 372 & 0.44 & 0.38 & & \\
\hline \multirow[t]{2}{*}{ RAD } & Female & 343 & 0.65 & 0.36 & $2.991 * *$ & .012 \\
\hline & Male & 372 & 0.57 & 0.37 & & \\
\hline
\end{tabular}

Table 8

Differences among participants' role and CWB-T factors $(N=718)$

\begin{tabular}{|c|c|c|c|c|c|c|c|}
\hline Factors & Role & $n$ & Mean & $S D$ & $F$ & $\eta^{2}$ & Tukey post-hoc \\
\hline \multirow[t]{5}{*}{ TT } & Subject teacher & 216 & 0.62 & 0.31 & $11.054 * * *$ & .059 & $\mathrm{C}>\mathrm{A}, \mathrm{B} ; \mathrm{E}>\mathrm{A}, \mathrm{B}, \mathrm{C}, \mathrm{D}$ \\
\hline & Teacher (+ class adviser) & 245 & 0.60 & 0.29 & & & \\
\hline & Teacher (+ administrator) & 185 & 0.72 & 0.30 & & & \\
\hline & Administrative staff & 40 & 0.72 & 0.29 & & & \\
\hline & School Principal & 26 & 0.93 & 0.14 & & & \\
\hline \multirow[t]{5}{*}{ IUR } & Subject teacher & 216 & 0.24 & 0.30 & $11.458 * * *$ & .061 & $\mathrm{C}>\mathrm{A}, \mathrm{B} ; \mathrm{B}>\mathrm{D} ; \mathrm{E}>\mathrm{A}, \mathrm{B}, \mathrm{C}$ \\
\hline & Teacher (+ class adviser) & 245 & 0.24 & 0.28 & & & \\
\hline & Teacher (+ administrator) & 185 & 0.35 & 0.30 & & & \\
\hline & Administrative staff & 40 & 0.38 & 0.32 & & & \\
\hline & School Principal & 26 & 0.54 & 0.18 & & & \\
\hline \multirow[t]{5}{*}{ ISR } & Subject teacher & 216 & 0.46 & 0.34 & $11.298 * * *$ & .060 & $\mathrm{C}>\mathrm{A}, \mathrm{B} ; \mathrm{E}>\mathrm{A}, \mathrm{B}, \mathrm{C}, \mathrm{D}$ \\
\hline & Teacher (+ class adviser) & 245 & 0.42 & 0.34 & & & \\
\hline & Teacher (+ administrator) & 185 & 0.56 & 0.35 & & & \\
\hline & Administrative staff & 40 & 0.56 & 0.33 & & & \\
\hline & School Principal & 26 & 0.80 & 0.21 & & & \\
\hline \multirow[t]{5}{*}{ IPR } & Subject teacher & 216 & 0.22 & 0.31 & $19.707 * * *$ & .100 & $\mathrm{C}>\mathrm{A}, \mathrm{B} ; \mathrm{E}>\mathrm{A}, \mathrm{B}, \mathrm{C}, \mathrm{D}$ \\
\hline & Teacher (+ class adviser) & 245 & 0.22 & 0.30 & & & \\
\hline & Teacher (+ administrator) & 185 & 0.38 & 0.36 & & & \\
\hline & Administrative staff & 40 & 0.37 & 0.36 & & & \\
\hline & School Principal & 26 & 0.68 & 0.26 & & & \\
\hline \multirow[t]{5}{*}{ LOP } & Subject teacher & 216 & 0.47 & 0.35 & $19.488 * * *$ & .099 & $\mathrm{C}>\mathrm{A}, \mathrm{B} ; \mathrm{E}>\mathrm{A}, \mathrm{B}, \mathrm{C}, \mathrm{D}$ \\
\hline & Teacher (+ class adviser) & 245 & 0.47 & 0.35 & & & \\
\hline & Teacher (+ administrator) & 185 & 0.65 & 0.37 & & & \\
\hline & Administrative staff & 40 & 0.60 & 0.35 & & & \\
\hline & School Principal & 26 & 0.96 & 0.11 & & & \\
\hline
\end{tabular}


Ching, G. S., Tsay, W.-R., Hu, Y.-L., \& Hung, C.-H.

Table 8 ... continued

\begin{tabular}{|c|c|c|c|c|c|c|c|}
\hline Factors & Role & $n$ & Mean & $S D$ & $F$ & $\eta^{2}$ & Tukey post-hoc \\
\hline \multirow[t]{5}{*}{$\mathrm{AP}$} & Subject teacher & 216 & 0.53 & 0.33 & $12.001 * * *$ & .064 & $\mathrm{C}>\mathrm{A}, \mathrm{B} ; \mathrm{E}>\mathrm{A}, \mathrm{B}, \mathrm{C}, \mathrm{D}$ \\
\hline & Teacher (+ class adviser) & 245 & 0.55 & 0.33 & & & \\
\hline & Teacher (+ administrator) & 185 & 0.67 & 0.35 & & & \\
\hline & Administrative staff & 40 & 0.65 & 0.35 & & & \\
\hline & School Principal & 26 & 0.90 & 0.16 & & & \\
\hline \multirow[t]{5}{*}{ PT } & Subject teacher & 216 & 0.40 & 0.37 & $17.004 * * *$ & .088 & $\mathrm{C}>\mathrm{A}, \mathrm{B} ; \mathrm{D}>\mathrm{A}, \mathrm{B} ; \mathrm{E}>\mathrm{A}, \mathrm{B}, \mathrm{C}$ \\
\hline & Teacher (+ class adviser) & 245 & 0.37 & 0.36 & & & \\
\hline & Teacher (+ administrator) & 185 & 0.55 & 0.37 & & & \\
\hline & Administrative staff & 40 & 0.63 & 0.37 & & & \\
\hline & School Principal & 26 & 0.82 & 0.27 & & & \\
\hline \multirow[t]{5}{*}{ RAD } & Subject teacher & 216 & 0.54 & 0.37 & $17.907 * * *$ & .092 & $\mathrm{C}>\mathrm{A}, \mathrm{B} ; \mathrm{D}>\mathrm{B} ; \mathrm{E}>\mathrm{A}, \mathrm{B}, \mathrm{C}, \mathrm{D}$ \\
\hline & Teacher (+ class adviser) & 245 & 0.52 & 0.36 & & & \\
\hline & Teacher (+ administrator) & 185 & 0.73 & 0.35 & & & \\
\hline & Administrative staff & 40 & 0.70 & 0.36 & & & \\
\hline & School Principal & 26 & 0.96 & 0.09 & & & \\
\hline
\end{tabular}

For the perceived variations in CWB with teachers' educational attainment and school size, ANOVA results noted that there are no significant differences with all the CWB-T factors. This would mean that CWBs is not just limited to big schools, even within small schools CWBs exists. More important, perception of CWBs is not affected by an individual's educational attainment.

As with the school locations to whether it is located in the Northern, Central, Southern, or Eastern Taiwan, ANOVA results show that there are significant differences with $F$ values ranging from 5.693 to 16.761 all with $p$ values ranging from .000 to .001 (see Table 9). As with the majority of respondents are from the Northern and Central Taiwan, comparison of the teachers working in the two regions would seem more relevant. Table 9 shows that the post-hoc analyses all noted that teachers who worked in Northern Taiwan perceived significant higher CWB occurrence than their Central Taiwan teacher counterparts. This results actually signifies that CWB occurrence are more prevalent in Northern Taiwan elementary and high schools, which is quite contrary to the notions that since the Northern region is the seat of Taiwan government; the MOE is quite visible and strict, CWB should be minimal. However, results might also indicate a different spectrum, wherein elementary and high school teachers in Central Taiwan are not that sensitive and/or knowledgeable with CWB issues.

Table 9

Differences among location and CWB-T factors (N=718)

\begin{tabular}{|c|c|c|c|c|c|c|c|}
\hline Factors & Locations & $n$ & Mean & $S D$ & $F$ & $\eta^{2}$ & Tukey post-hoc \\
\hline \multirow[t]{4}{*}{ TT } & North Taiwan & 310 & 0.70 & 0.30 & $5.734 * *$ & .024 & $A>B$ \\
\hline & Central Taiwan & 343 & 0.61 & 0.31 & & & \\
\hline & South Taiwan & 60 & 0.65 & 0.27 & & & \\
\hline & East Taiwan & 5 & 0.80 & 0.24 & & & \\
\hline \multirow[t]{4}{*}{ IUR } & North Taiwan & 310 & 0.33 & 0.31 & $5.693 * *$ & .023 & $\mathrm{~A}>\mathrm{B}$ \\
\hline & Central Taiwan & 343 & 0.24 & 0.28 & & & \\
\hline & South Taiwan & 60 & 0.28 & 0.30 & & & \\
\hline & East Taiwan & 5 & 0.45 & 0.21 & & & \\
\hline \multirow[t]{4}{*}{ ISR } & North Taiwan & 310 & 0.56 & 0.34 & $8.811 * * *$ & .036 & $\mathrm{~A}>\mathrm{B}$ \\
\hline & Central Taiwan & 343 & 0.43 & 0.34 & & & \\
\hline & South Taiwan & 60 & 0.48 & 0.36 & & & \\
\hline & East Taiwan & 5 & 0.71 & 0.29 & & & \\
\hline \multirow[t]{4}{*}{ IPR } & North Taiwan & 310 & 0.36 & 0.36 & $12.393 * * *$ & .049 & $\mathrm{~A}>\mathrm{B} ; \mathrm{D}>\mathrm{B}$ \\
\hline & Central Taiwan & 343 & 0.21 & 0.30 & & & \\
\hline & South Taiwan & 60 & 0.27 & 0.34 & & & \\
\hline & East Taiwan & 5 & 0.60 & 0.42 & & & \\
\hline
\end{tabular}


Table 9 ... continued

\begin{tabular}{|c|c|c|c|c|c|c|c|}
\hline Factors & Locations & $n$ & Mean & $S D$ & $F$ & $\eta^{2}$ & Tukey post-hoc \\
\hline \multirow[t]{4}{*}{ LOP } & North Taiwan & 310 & 0.62 & 0.36 & $10.825 * * *$ & .044 & $\mathrm{~A}>\mathrm{B}$ \\
\hline & Central Taiwan & 343 & 0.47 & 0.36 & & & \\
\hline & South Taiwan & 60 & 0.50 & 0.38 & & & \\
\hline & East Taiwan & 5 & 0.80 & 0.18 & & & \\
\hline \multirow[t]{4}{*}{ AP } & North Taiwan & 310 & 0.69 & 0.33 & $16.761 * * *$ & .066 & $\mathrm{~A}>\mathrm{B}, \mathrm{C}$ \\
\hline & Central Taiwan & 343 & 0.51 & 0.34 & & & \\
\hline & South Taiwan & 60 & 0.51 & 0.33 & & & \\
\hline & East Taiwan & 5 & 0.83 & 0.29 & & & \\
\hline \multirow[t]{4}{*}{$\mathrm{PT}$} & North Taiwan & 310 & 0.55 & 0.38 & $11.618 * * *$ & .047 & $\mathrm{~A}>\mathrm{B}$ \\
\hline & Central Taiwan & 343 & 0.38 & 0.37 & & & \\
\hline & South Taiwan & 60 & 0.45 & 0.34 & & & \\
\hline & East Taiwan & 5 & 0.49 & 0.41 & & & \\
\hline \multirow[t]{4}{*}{ RAD } & North Taiwan & 310 & 0.71 & 0.35 & $15.604 * * *$ & .062 & $\mathrm{~A}>\mathrm{B}, \mathrm{C}$ \\
\hline & Central Taiwan & 343 & 0.52 & 0.36 & & & \\
\hline & South Taiwan & 60 & 0.55 & 0.39 & & & \\
\hline & East Taiwan & 5 & 0.65 & 0.42 & & & \\
\hline
\end{tabular}

For the difference in schools either located in the City (urban), Rural, or in the Remote areas of Taiwan, ANOVA results show that only the CWB-T factor AP is noted with $F(3,714)=4.135, p=.016$, hence, significant differences are found. While, post-hoc analysis shows that schools located in the City are perceived to have more CWBs than their Rural school counterparts (see Table 10). In some sense this result signifies that teachers who worked in city schools show less concern towards their students. It is hypothesized that work conditions and/or the stress connected in teaching within major cities as primary source of apathy. In other words, teachers in the city tend to get burn-out more often than the teachers who teach in the rural areas. Further analysis on this issue is suggested to future researcher on topics related to in schools CWBs.

\section{Table 10}

Differences among school district and CWB-T factors $(N=718)$

\begin{tabular}{|c|c|c|c|c|c|c|c|}
\hline Factors & District & $n$ & Mean & $S D$ & $F$ & $\eta^{2}$ & Tukey post-hoc \\
\hline \multirow[t]{3}{*}{$\mathrm{TT}$} & Urban/City & 490 & 0.65 & 0.31 & 0.907 & .003 & \\
\hline & Rural & 186 & 0.68 & 0.29 & & & \\
\hline & Remote & 42 & 0.64 & 0.29 & & & \\
\hline \multirow[t]{3}{*}{ IUR } & Urban/City & 490 & 0.27 & 0.29 & 1.983 & .006 & \\
\hline & Rural & 186 & 0.32 & 0.31 & & & \\
\hline & Remote & 42 & 0.28 & 0.30 & & & \\
\hline \multirow[t]{3}{*}{ ISR } & Urban/City & 490 & 0.48 & 0.35 & 1.175 & .003 & \\
\hline & Rural & 186 & 0.52 & 0.34 & & & \\
\hline & Remote & 42 & 0.52 & 0.38 & & & \\
\hline \multirow[t]{3}{*}{ IPR } & Urban/City & 490 & 0.28 & 0.34 & 1.248 & .003 & \\
\hline & Rural & 186 & 0.28 & 0.33 & & & \\
\hline & Remote & 42 & 0.36 & 0.35 & & & \\
\hline \multirow[t]{3}{*}{ LOP } & Urban/City & 490 & 0.53 & 0.37 & 1.151 & .003 & \\
\hline & Rural & 186 & 0.56 & 0.35 & & & \\
\hline & Remote & 42 & 0.60 & 0.36 & & & \\
\hline \multirow[t]{3}{*}{ AP } & Urban/City & 490 & 0.57 & 0.35 & $4.135^{*}$ & .011 & Urban/City > Rural \\
\hline & Rural & 186 & 0.65 & 0.32 & & & \\
\hline & Remote & 42 & 0.62 & 0.31 & & & \\
\hline \multirow[t]{3}{*}{ PT } & Urban/City & 490 & 0.44 & 0.38 & 1.271 & .004 & \\
\hline & Rural & 186 & 0.49 & 0.38 & & & \\
\hline & Remote & 42 & 0.50 & 0.33 & & & \\
\hline \multirow[t]{3}{*}{ RAD } & Urban/City & 490 & 0.59 & 0.38 & 2.349 & .007 & \\
\hline & Rural & 186 & 0.64 & 0.36 & & & \\
\hline & Remote & 42 & 0.70 & 0.32 & & & \\
\hline
\end{tabular}




\section{Table 11}

Differences among years of service and CWB-T factors $(N=718)$

\begin{tabular}{|c|c|c|c|c|c|c|}
\hline Factors & Years of service & $n$ & Mean & $S D$ & $F$ & Tukey post-hoc \\
\hline \multirow[t]{6}{*}{ TT } & 1 to 5 years & 179 & 0.59 & 0.30 & 3.043* & .022 \\
\hline & 6 to 10 years & 169 & 0.68 & 0.28 & & \\
\hline & 11 to 15 years & 118 & 0.63 & 0.34 & & \\
\hline & 16 to 20 years & 126 & 0.68 & 0.30 & & \\
\hline & 21 to 25 years & 69 & 0.67 & 0.29 & & \\
\hline & More than 26 years & 10 & 0.84 & 0.23 & & \\
\hline \multirow[t]{6}{*}{ IUR } & 1 to 5 years & 179 & 0.20 & 0.28 & 4.839*** & $.035 \quad \mathrm{~B}>\mathrm{A} ; \mathrm{D}>\mathrm{A}$ \\
\hline & 6 to 10 years & 169 & 0.29 & 0.31 & & \\
\hline & 11 to 15 years & 118 & 0.28 & 0.29 & & \\
\hline & 16 to 20 years & 126 & 0.35 & 0.30 & & \\
\hline & 21 to 25 years & 69 & 0.29 & 0.28 & & \\
\hline & More than 26 years & 10 & 0.45 & 0.31 & & \\
\hline \multirow[t]{6}{*}{ ISR } & 1 to 5 years & 179 & 0.43 & 0.34 & $3.746 * *$ & $.027 \mathrm{D}>\mathrm{A} ; \mathrm{F}>\mathrm{A}$ \\
\hline & 6 to 10 years & 169 & 0.46 & 0.34 & & \\
\hline & 11 to 15 years & 118 & 0.46 & 0.33 & & \\
\hline & 16 to 20 years & 126 & 0.55 & 0.34 & & \\
\hline & 21 to 25 years & 69 & 0.53 & 0.37 & & \\
\hline & More than 26 years & 10 & 0.76 & 0.33 & & \\
\hline \multirow[t]{6}{*}{ IPR } & 1 to 5 years & 179 & 0.22 & 0.32 & $3.629 * *$ & $.027 \quad \mathrm{~F}>\mathrm{A}$ \\
\hline & 6 to 10 years & 169 & 0.26 & 0.32 & & \\
\hline & 11 to 15 years & 118 & 0.25 & 0.32 & & \\
\hline & 16 to 20 years & 126 & 0.33 & 0.35 & & \\
\hline & 21 to 25 years & 69 & 0.34 & 0.36 & & \\
\hline & More than 26 years & 10 & 0.54 & 0.30 & & \\
\hline \multirow[t]{6}{*}{ LOP } & 1 to 5 years & 179 & 0.49 & 0.36 & 2.692* & .020 \\
\hline & 6 to 10 years & 169 & 0.51 & 0.35 & & \\
\hline & 11 to 15 years & 118 & 0.48 & 0.38 & & \\
\hline & 16 to 20 years & 126 & 0.60 & 0.37 & & \\
\hline & 21 to 25 years & 69 & 0.59 & 0.37 & & \\
\hline & More than 26 years & 10 & 0.72 & 0.34 & & \\
\hline \multirow[t]{6}{*}{ AP } & 1 to 5 years & 179 & 0.52 & 0.32 & 2.909* & $.021 \quad \mathrm{D}>\mathrm{A}$ \\
\hline & 6 to 10 years & 169 & 0.57 & 0.34 & & \\
\hline & 11 to 15 years & 118 & 0.58 & 0.36 & & \\
\hline & 16 to 20 years & 126 & 0.64 & 0.32 & & \\
\hline & 21 to 25 years & 69 & 0.64 & 0.35 & & \\
\hline & More than 26 years & 10 & 0.75 & 0.30 & & \\
\hline \multirow[t]{6}{*}{ PT } & 1 to 5 years & 179 & 0.40 & 0.37 & $3.504 * *$ & $.026 \quad \mathrm{~F}>\mathrm{A}$ \\
\hline & 6 to 10 years & 169 & 0.45 & 0.36 & & \\
\hline & 11 to 15 years & 118 & 0.40 & 0.37 & & \\
\hline & 16 to 20 years & 126 & 0.51 & 0.38 & & \\
\hline & 21 to 25 years & 69 & 0.53 & 0.38 & & \\
\hline & More than 26 years & 10 & 0.74 & 0.34 & & \\
\hline \multirow[t]{6}{*}{ RAD } & 1 to 5 years & 179 & 0.54 & 0.39 & $4.597 * * *$ & $.033 \mathrm{D}>\mathrm{A}, \mathrm{C} ; \mathrm{F}>\mathrm{A}, \mathrm{C}$ \\
\hline & 6 to 10 years & 169 & 0.60 & 0.37 & & \\
\hline & 11 to 15 years & 118 & 0.55 & 0.39 & & \\
\hline & 16 to 20 years & 126 & 0.68 & 0.32 & & \\
\hline & 21 to 25 years & 69 & 0.66 & 0.35 & & \\
\hline & More than 26 years & 10 & 0.93 & 0.17 & & \\
\hline
\end{tabular}

Lastly, for the differences with the perceived CWBs in teachers' years of service, Table 11 shows that there are significant differences in all the CWB-T factors with $F$ value ranging from 2.692 to 4.839 and $p$ value ranging from .000 to 0.20 . Post-hoc analysis denotes the trend of faculty that worked longer (seniority) perceived 
higher CWBs than their younger counterparts. Similar with the findings on the differences in teachers' role or position, data suggest that faculty with higher years of service tend to have greater opportunity to observed what is really happening inside the school, hence, higher perception of CWB occurrence.

\section{Conclusions}

Occurrence of CWBs inside the school is a reality. Results of the current study clearly noted that the perceived CWB-T factors TT and RAD as the two highest occurring deviant behaviors within the school. Analyzing the results, the TT item "Doing personal stuff while on duty" was perceived the highest with a mean value of 0.86 , this roughly translate to occurring around $86 \%$ of the time. Within the RAD items, "Unwilling to undertake administrative responsibilities" with mean value of 0.75 and the item "Miscommunication between teachers and administrators" with mean value of 0.69 , both are crucial to the smooth operations within the school. Furthermore, ISR item "Favoritism or discriminating specific students" with mean value of 0.72 and item "Improper student punishment" with mean value of 0.62, LOP item "Too few or too much assignments/class activities" with mean value of 0.69, AP item "Lacks teaching enthusiasm" with mean value of 0.73 and item "Wrong use of educational resources" with mean value of 0.75 , and PT item "Gossiping" with mean value of 0.72 , all of which can be said to occur more than half of the time.

As for the differences with regards to the participants' background demography, results suggest that teachers with administrative duties, teachers with longer years of service, teachers working in urban cities, and teachers who are working in the key capital region all seem to perceived higher occurrence of CWBs within the academic workplace. While, no perceived significant differences are found in teachers with different educational attainment and school sizes, these further suggests that no matter what size of the school is and to what level of education the teachers has, CWBs are still present. In sum, as awareness of CWBs within academic institutions increases, it is hoped that this type of study would be able to shed light and help policy makers design better strategies to help remedy the situation.

Acknowledgement: This work is supported in part by the Taiwan Ministry of Science and Technology projects 103-2410-H-004-143 and 104-2410-H-004-151-SS2. Part of this paper is accepted for presentation in the 2016 Lumina Research Congress to be held in Hong Kong from 29 to 30 October 2016 and is also included in the Conference Book of Proceedings.

\section{References}

Andrews, P., \& Meyer, R. G. (2003). Marlowe-Crowne social desirability scale and short form C: Forensic norms. Journal of Clinical Psychology, 59(4), 483-492. http://dx.doi.org/10.1002/jclp.10136

Barger, S. D. (2002). The Marlowe-Crowne affair: Short forms, psychometric structure, and social desirability. Journal of Personality Assessment, 79(2), 286-305. http://dx.doi.org/10.1207/S15327752JPA7902_11

Bayram, N., Gursakal, N., \& Bilgel, N. (2009). Counterproductive work behavior among white-collar employees: A study from Turkey. International Journal of Selection and Assessment, 17(2), 180-188. http://dx.doi.org/10.1111/j.1468-2389.2009.00461.x

Belogolovsky, E., \& Somech, A. (2010). Teachers' organizational citizenship behavior: Examining the boundary between in-role behavior and extra-role behavior from the perspective of teachers, principals and parents. Teaching and Teacher Education, 26(4), 914-923. http://dx.doi.org/10.1016/j.tate.2009.10.032

Cohen, L., Manion, L., \& Morrison, K. (2007). Research methods in education. New York: Routledge.

Cronbach, L. J. (1951). Coefficient alpha and the internal structure of tests. Psychometrika, 16, $197-334$. http://dx.doi.org/10.1007/BF02310555

Dalal, R. S. (2005). A meta-analysis of the relationship between organizational citizenship behavior and counterproductive work behavior. Journal of Applied Psychology, 90(6), 1241-1255. http://dx.doi.org/10.1037/0021-9010.90.6.1241

Fischer, D. G., \& Fick, C. (1993). Measuring social desirability: Short forms of the Marlowe-Crowne social desirability scale. Educational and Psychological Measurement, 53(2), 417-424. 
Ching, G. S., Tsay, W.-R., Hu, Y.-L., \& Hung, C.-H.

http://dx.doi.org/10.1177/0013164493053002011

Fornell, C., \& Larcker, D. F. (1981). Evaluating structural equation models with unobservable variables and measurement error. Journal of Marketing Research, 18(1), 39-50. http://dx.doi.org/10.2307/3151312

Fox, S., Spector, P. E., \& Miles, D. (2001). Counterproductive work behavior (CWB) in response to job stressors and organizational justice: Some mediator and moderator tests for autonomy and emotions. Journal of Vocational Behavior, 59(3), 291-309. http://dx.doi.org/10.1006/jvbe.2001.1803

Fox, S., \& Stallworth, L. E. (2010). The battered apple: An application of stressor-emotion-control/support theory to teachers' experience of violence and bullying. Human Relations, 63(7), 927-954. http://dx.doi.org/10.1177/0018726709349518

Gruys, M. L., \& Sackett, P. R. (2003). Investigating the dimensionality of counterproductive work behavior. International Journal of Selection and Assessment, 11(1), 30-42. http://dx.doi.org/10.1111/1468-2389.00224

Hu, Y.-L., Hung, C.-H., \& Ching, G. S. (2015). Examining the counterproductive work behaviors within Taiwan academic setting: A pilot study. Higher Education Evaluation and Development, 9(1), 63-82. http://dx.doi.org/10.6197/HEED.2015.0901.04

Hung, C.-L. (2011). Coping strategies of primary school teachers in Taiwan experiencing stress because of teacher surplus. Social Behavior and Personality, 39(9), 1161-1174.

Kenny, D. A. (2015). Measuring model fit. Retrieved from http://davidakenny.net/cm/fit.htm

Kenny, D. A. (2016). Multiple latent variable models: Confirmatory factor analysis. Retrieved from http://davidakenny.net/cm/mfactor.htm

Kyriacou, C., \& Chien, P.-Y. (2004). Teacher stress in Taiwanese primary schools [Online]. The Journal of Educational Enquiry, 5(2).

Leite, W. L., \& Beretvas, S. N. (2005). Validation of scores on the Marlowe-Crowne social desirability scale and the balanced inventory of desirable responding. Educational and Psychological Measurement, 65(1), 140-154. http://dx.doi.org/10.1177/0013164404267285

Likert, R. (1932). A technique for the measurement of attitudes. New York: Columbia University Press.

Loo, R., \& Thorpe, K. (2000). Confirmatory factor analyses of the full and short versions of the Marlowe-Crowne social desirability scale. The Journal of Social Psychology, 140(5), 628-635. http://dx.doi.org/10.1080/00224540009600503

Oplatka, I. (2009). Organizational citizenship behavior in teaching: The consequences for teachers, pupils, and the school. International Journal of Educational Management, 23(5), 375-389. http://dx.doi.org/10.1108/09513540910970476

Robinson, S. L., \& Bennett, R. J. (1995). A typology of deviant workplace behaviors: A multidimensional scaling study. Academy of Management Journal, 38(2), 555-572.

Sackett, P. R. (2002). The structure of counterproductive work behaviors: Dimensionality and relationships with facets of job performance. International Journal of Selection and Assessment, 10(1-2), 5-11. http://dx.doi.org/10.1111/1468-2389.00189

Salami, S. O. (2010). Job stress and counterproductive work behavior: Negative affectivity as a moderator. The Social Sciences, 5(6), 486-492.

Spector, P. E., Fox, S., Penney, L. M., Bruursema, K., Goh, A., \& Kessler, S. (2006). The dimensionality of counterproductivity: Are all counterproductive behaviors created equal? Journal of Vocational Behavior, 68(3), 446-460. http://dx.doi.org/10.1016/j.jvb.2005.10.005

Thompson, E. R., \& Phua, F. T. (2005). Reliability among senior managers of the Marlowe-Crowne short-form social desirability scale. Journal of Business and Psychology, 19(4), 541-554. http://dx.doi.org/10.1007/s10869-005-4524-4

Walker, I. (2010). Research methods and statistics. New York, NY: Palgrave Macmillan.

Weisberg, H. F., Kronsnick, J. A., \& Bowen, B. D. (1996). An introduction to survey research, polling, and data analysis (3rd ed.). Thousand Oaks, CA: Sage. 